\title{
INTELLECTUAL CAPITAL, FINANCIAL CRISIS AND PERFORMANCE OF ISLAMÍC BANKS: DOES SHARIAH GOVERNANCE MATTER?
}

\author{
Tasawar Nawaz* \\ University of Plymouth
}

\begin{abstract}
This paper empirically examines the impact of intellectual capital (IC) and Shariah governance on economic performance of 47 Islamic banks (IBs) operating in the Gulf Cooperation Council (GCC) region in pre- and post-financial crisis period. The analysis suggests that higher IC efficiency helps IBs to improve their odds of survival at all times i.e. before- and after-crisis. Further, higher IC efficiency helps IBs to maintain their profitability i.e. ROA and market valuation i.e. Tobin's Q at all times. Arguably, knowledge-resources i.e. IC is the main line of defence for IBs against negative shocks. Lastly, the study reveals that Shariah governance alone may fall short in explaining the growth trends in Islamic finance industry.
\end{abstract}

Keywords: Intellectual Capital; Shariah Governance; Financial Crisis; Islamic Worldview; Economic Performance.

\section{INTRODUCTION}

Since its inception in 1975, Islamic banking and finance has grown unabatedly and it is now considered as one of the fastest growing segments in the field of finance. According to the World Islamic Banking Competitiveness Report, Islamic banking is growing at the rate of $15 \%$ to $20 \%$ per annum globally with assets held by Islamic banks are set to exceed USD2 trillion in 2013 (Nazim \& Bennie, 2012). Islamic finance has increasingly carved out a significant slice of the global financial market (Mallin, Farag, \& Ow-Yong, 2014). It has become systemically important in many markets and too big to ignored in others i.e. Europe and the Americas (Nawaz, 2013, 2015).

Given the robust growth of Islamic finance industry and its resilience during the financial crisis, has attracted the attention of many research intellectuals. An emerging body of literature has attempted to identify and examine distinct features of Islamic banking and finance. The aspects investigated are but not limited to asset quality (Beck, Demirgüç-Kunt, \& Merrouche, 2013), stability (Čihák \& Hesse, 2010; Hasan \& Dridi, 2010), efficiency (Bourkhis \& Nabi, 2013; Majid, Saal, \& Battisti, 2010), valuation (Elnahass, Izzeldin, \& Abdelsalam, 2014), risk (Abedifar, Molyneux, \& Tarazi, 2013), relationship banking (Ongena \& Şendeniz-Yüncü, 2011), mutual funds (Abdelsalam, Fethi, Matallín, \& TortosaAusina, 2014), mortgage loans (Ebrahim, 2009) and other risk dimensions such as loan

\footnotetext{
*Corresponding author: Plymouth Business School, University of Plymouth PL4 8AA United Kingdom. Email: tnawaz@plymouth.ac.uk
} 
default rates (Baele, Farooq, \& Ongena, 2014; Khan, 2010). The foregoing empirical literature posit for the sound financial health of Islamic finance industry (Nawaz, 2017) and reports an upward trend in the growth of total assets held by the Islamic banks (Beck et al., 2013; Hasan \& Dridi, 2010; Johnes, Izzeldin, \& Pappas, 2014).

While the afore cited studies are clearly important but they have examined the effects of tangible or financial assets on bank performance and paid little attention to the investigation of how financial intermediaries exploit their intangible resources (i.e. intellectual capital), which helps an organization to maintain its profitability and sustain competitive advantage in the market. IC is highly significant to Islamic banks (IBs) because the whole phenomenon of Islamic banking is based on the Shariah law, an intangible ideology. Therefore, knowing how intangible aspects (i.e. IC) affect IBs' performance, is of paramount importance.

In chorus, the empirical evidence also suggests that the recent financial crisis is to a large extent attributable to lax governance in the banking sector. Kashyap, Rajan, and Stein (2008), for instance, reasons that firms' risk management and financing policies are ultimately the outcome of cost-benefit trade-offs made by governing bodies, suggesting that corporate governance have had impact on firm performance during the financial crisis (Erkens, Hung, \& Matos, 2012). Equally, academics and policymakers have also emphasized that flaws in bank governance played a key role in the performance of banks during the crisis (e.g., Bebchuk \& Spamann, 2009; Diamond \& Rajan, 2009). Governance features especially, Shariah governance is a distinguishing feature of Islamic banking in determining IBs' performance. However, the empirical evidence on the said matter is limited and shallow.

Against this back ground the main purpose of this paper is to analyse the impact of intellectual capital and Shariah governance on the accounting- and market-based performance of Islamic banks in the pre- and post-financial crisis period.

\section{BACKGROUND}

\subsection{Financial crisis and Islamic banking}

Led by the intensity of the recent financial crisis, academics and policy makers have expressed concerns about the merits of laissez-faire capitalism and flawlessness of the centuries old orthodox banking model (Chen et al., 2014). As a consequence, an emerging body of literature has attempted to identify and examine how macro- and micro-economic factors may have impact on banks' performance (see inter alia Athanasoglou, Brissimis, \& Delis, 2008; Beltratti \& Stulz, 2012; Dietrich \& Wanzenried, 2011; Garcia-Appendini \& Montoriol-Garriga, 2013). At the crux of these studies is that a combination of macroeconomic factors such as loose monetary policies (Erkens et al., 2012), complex securitizations (Taylor, 2009), innovation of complex financial structures (Haneef \& Smolo, 2014), and lax corporate governance (Bebchuk \& Spamann, 2009; Diamond \& Rajan, 2009) have contributed to making the financial crisis as serious as it was. The financial crisis of 2007-08 shook the foundations of the centuries old financial system and has shed doubts on the proper functioning of conventional banking model. While radical transformation may threaten the profitability and survival of existing incumbent conventional financial 
institutions, it may also bring a cohort of new opportunities and powerful new players such as Islamic banks into the limelight as a possible and viable alternative. Before moving any further, it is imperative to comprehend the basic roots of Islamic way of banking.

\subsection{The Islamic worldview}

The Islamic worldview is basically a theistic and ethical worldview which contrasts sharply with the secularist or atheistic alternatives. There is no bifurcation of the world or duality in the Islamic worldview. The Islamic worldview is based on three pillars namely Allah the God), Qur'an (the world of Allah); and Hadith -sayings, approvals, and actions of the prophet Muhammad (PBUH) in his lifetime (Haniffa \& Hudaib, 2002).

Figure 1: Islamic Worldview and Sources of Shariah

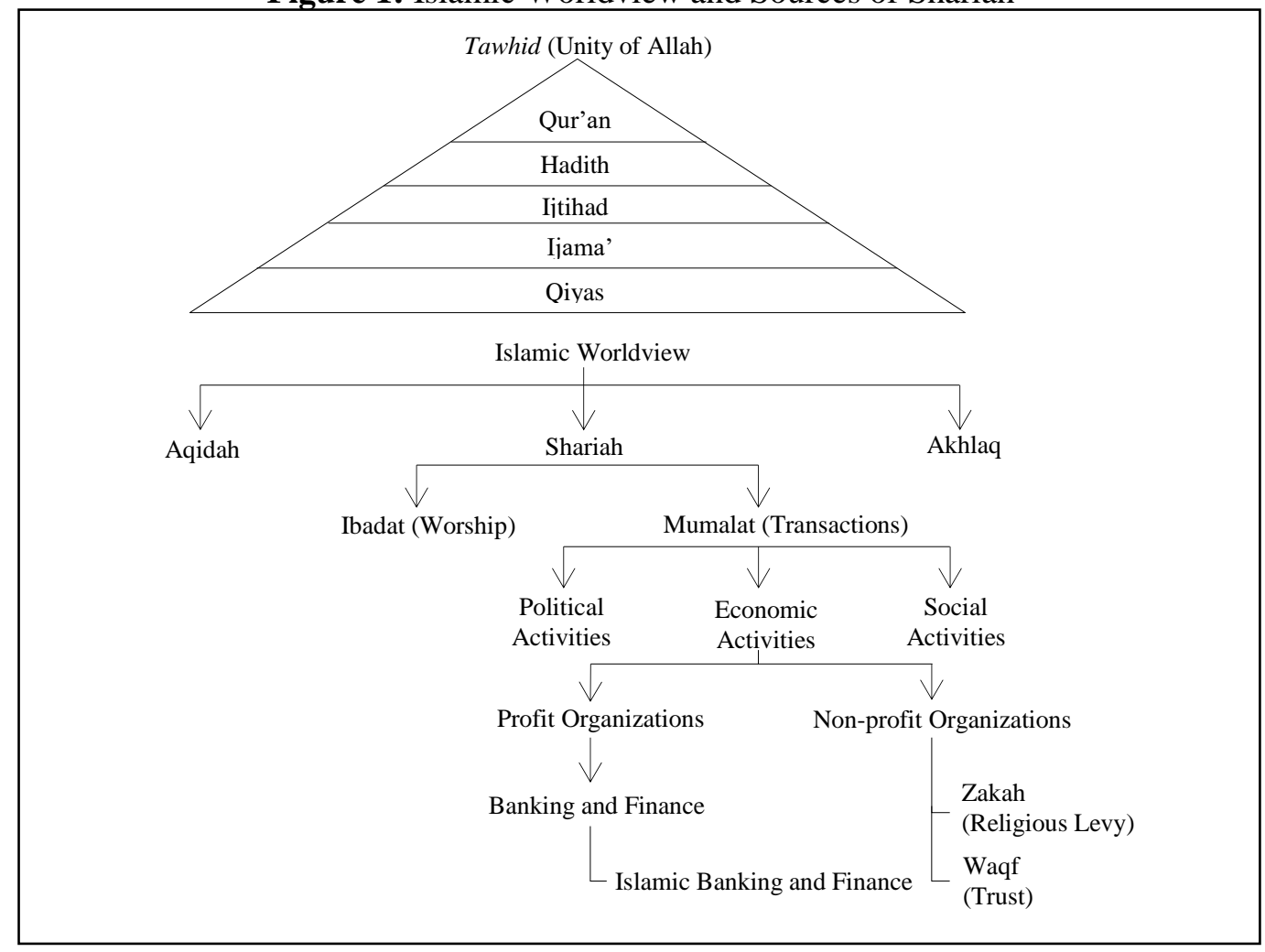

The individual and societal life of a Muslim is governed by certain sets of rules defined in Shariah. Islam makes no distinction between religion and daily life. The guidelines, provided in Shariah, are not subject to religious matters alone; it gives advice on all aspects of human life. Therefore, Islam may be perceived as comprising of three basic elements or sets of rules.

The first set of rules known as Aqida (faith) is subject to the core relationship between man and his creator (Allah). The second set-Akhlaq (morals and ethics) is concern with behaviour, attitude, and work ethics according to which a Muslim lives in society. The third and final set 
of rules is concerned with transforming and manifesting the faith and beliefs into action and daily practices -formally known as Shariah (for details, see Figure 1).

Shariah, being the practical aspect, provide guidelines on everyday life. Furthermore, it is divided into two components. The first is Ibadat (worship); this is subject to the practicalities of ways to perform rites and rituals. The second is Muamalat (transactions or man-to-man activities). This includes rules to govern social, political, and economic activities. The conduct of economic activities within the economic system, which includes the rules for commercial, financial and banking system means that Islamic banking is a part of this system.

Thus, banking and finance activities can be traced through the economic activities, back to daily life dealings and finally to Shariah. Thus, it is established that the whole phenomenon of Islamic banking is based on an intangible ideology (i.e. Shariah law) and intangibility is at the core of the concept of IC. Hence, IC is closely related to Islamic way of banking. Therefore, it is crucial to understand how IC impacts the corporate performance of IBs.

\subsection{Intellectual capital}

Stewart and Ruckdeschel (1998) posit that every business relies increasingly on knowledge and old-fashioned experience. Added together, this knowledge is intellectual capital and it can be defined as the sum of everything everybody in the company knows that will help to provide a competitive edge in the market. According to Sullivan (2000), IC basically constitutes knowledge, lore and innovations while Sveiby (1997) describes IC as the knowledge, experience, employee intellect and knowledge resources stocked up in an organization's databases system processes, culture and philosophy. IC can be further broken down into various components. Edvinsson and Malone (1997) classified IC into human capital and structural capital. The former is grounded on the knowledge created and stored by a firm's employees while the latter is based on the embodiment, empowerment and supportive infrastructure of human capital.

\section{DEVELOPMENT OF HYPOTHESIS}

\subsection{Intellectual capital efficiency and performance}

Various authorities argue that value creation in the knowledge-intensive sectors such as the banking industry require both IC and physical assets (Chen et al., 2014; Holland, 2010). Holland (2010) reveals how IC and financial resources impact on the value creation process in banking. Likewise, Chen et al. (2014, p. 566) regards IC and knowledge-based intangibles as the primary sources of sustainable competitive advantage in banking. On the other hand, at times the extent literature tends to treat the sub-components of IC i.e. human IC and structural IC as completely independent construct, thereby losing sight of the whole, IC. Youndt, Subramaniam, and Snell (2004) posits that treating human IC, and structural IC as discrete, unidimensional phenomena tends to simplify reality by not explicitly acknowledging the potential patterns of coexistence among these differing types of IC. Therefore, suggests that in order to fully understand how IC develops and drives performance, it may be helpful to look at an organization's overall profile of IC in the aggregate rather than independently focusing on individual parts. 
Accordingly, it is expected that the higher a firm's aggregate stock of IC, the more successful the firm will be and the greater will be its competitive advantage. In other words, the higher the value added intellectual coefficient of IC (VAIC) that the IB has, the higher will be its economic performance at all times i.e. pre- and post-financial crisis. Hence, the main hypothesis to be tested is that IC enhances the survival probability of an IB in normal times as well as during financial meltdown. Therefore, the first set of hypotheses is as follows:

Hypothesis 1.1: There is a significant positive relationship between VAIC and financial performance of IBs based on ROA in pre- and post-financial crisis period

Hypothesis 1.2: There is a significant positive relationship between VAIC and market performance of IBs based on Tobin's Q in pre- and post-financial crisis period

\subsection{Human capital efficiency (HCE) and performance}

Human capital in Dotzel, Shankar, and Berry (2013) is a critical organisational capability which corresponds directly to the propensity to service innovativeness to satisfy customer needs and improve firm value. Likewise, Colombo and Grilli (2005) suggest that firms with greater human IC (i.e. higher education or skill) are likely to have better entrepreneurial judgment and as long as human IC continues to be developed, staff can improve their job performance and ultimately improve the firm's performance.

In the case of IBs human IC is important as employees are expected to not only have conventional knowledge and skills related to the provision of such services but also having good knowledge on Shariah as this will enhance the credibility and reputation of IBs in the market place. The knowledge embedded in the human IC employed by the IBs is valuable, rare, and isolated from imitation or substitution. The resource-based view of the firm gives rise to the following hypotheses:

Hypothesis 1.1a: There is a significant positive relationship between HCE and financial performance of IBs based on ROA in pre- and post-financial crisis period

Hypothesis 1.2a: There is a significant positive relationship between HCE and market performance of IBs based on Tobin's Q in pre- and post-financial crisis period

\subsection{Structural capital efficiency (SCE) and performance}

Structural IC provides an environment which enables an organization to create and leverage knowledge. An organization with strong structural IC will have a supportive culture that encourages employees to try and learn new knowledge (Florin, Lubatkin, \& Schulze, 2003). De Brentani and Kleinschmidt (2004) suggest that an organization's operation processes and the organizational commitment of sufficient resources have a significant impact on performance. Likewise, Hsu and Wang (2012) posit that structural IC, i.e. operations, procedures and the processes of knowledge management, propels organizations' value creation activities which have a positive effect on their performance.

IBs adopt different structural process and system to track and record their transactions hence, requires development and investment in the structural processes that will enhance their performance. This argument is in line with the resource-based view of the firm, which attributes superior economic performance to organizational resources and 
capabilities (Bharadwaj, 2000). Since RBV explicitly recognizes the importance of tangible and intangibles, it offers a significant opportunity to explore these theoretical complementarities in examining the relationship between structural IC resources and the economic performance of IBs. Therefore, the next set of hypotheses is as follows:

Hypothesis 1.1b: There is a significant positive relationship between SCE and financial performance of IBs based on ROA in pre- and post-financial crisis period

Hypothesis 1.2b: There is a significant positive relationship between SCE and market performance of IBs based on Tobin's Q in pre- and post-financial crisis period

\subsection{Capital employed efficiency (CEE) and performance}

Research generally, explains that IC has to be contextualized by other resources including physical and financial ones (Chen et al., 2014; de Castro \& Sáez, 2008; Murthy \& Mouritsen, 2011). At the crux of theses research is that IC does have the positive agenda of growth proposed by the IC model where it is understood to bring financial capital forward. Murthy and Mouritsen (2011), in response, analysed the relationship between IC and financial capital and submit that higher firm performance is subject to the combination of firm's IC and financial capital. Likewise, most recent empirical evidence Beltratti and Stulz (2012), Berger and Bouwman (2013), and Chen et al. (2014) posit that strong capital base helps bank to enhance the survival probability and market share at all times.

Since no interest is involved in Islamic way of banking and profit is solely earned through employing capital in different projects, therefore, it is expected that the efficiency of capital employed to be positively associated with the overall performance of IBs. Hence, the next hypotheses are;

Hypothesis 1.1c: There is a significant positive relationship between CEE and financial performance of IBs based on ROA in pre- and post-financial crisis period

Hypothesis 1.2c: There is a significant positive relationship between CEE and market performance of IBs based on Tobin's Q in pre- and post-financial crisis period

\subsection{Shariah governance and performance}

The underlying principle of Islamic banking and finance is Shariah-compatibility in all of its products and services (Nawaz, 2016). In order to comply with this rule, IBs are cogoverned by Shariah scholars who specialize in Islamic law and jurisprudence with some having, also, a background in economics and finance (Ahmed, 2011).

Generally, any financial institution offering Shariah-compliant products and services is obligated to have its own permanent independent Shariah Supervisory Board (SSB). However different Shariah organs, ranging from an in-house Shariah-compliance unit, internal Shariah audit and review to SSB, can be found across the whole Islamic finance industry. At the core of such Shariah organs is the agenda to implement a Shariah governance framework and to lay guidelines which are necessary to reduce Shariahcompliance risks and to ensure that the IBs fulfil their fiduciary duties of conducting business according to Shariah principles (see Ahmed, Mehmet, \& Rodney, 2014). 
The prime obligations of SSB in Ahmed et al. (2014) are; 1) to ensure the Shariahcompliancy of all contracts offered by IBs, 2) to help IBs mitigate the effects of potential risk through due diligence by abiding the ethical foundations of Islamic moral economy, and 3) to perform Shariah-audit to satisfy the stakeholders as it does not operate as an $e x$ post compliance medium. Therefore, it is imperative to analyse how Shariah-governance, measure by SSB size influence the performance of IBs;

Hypothesis 2.1: There is a significant relationship between SSB-size and financial performance of IBs based on ROA in pre- and post-financial crisis period

Hypothesis 2.2: There is a significant relationship between SSB-size and market performance of IBs based on Tobin's Q in pre- and post-financial crisis period

\section{METHODOLOGY, VARIABLES AND DATA}

The financial data is drawn from BankScope database where as the Shariah governance related data is hand collected from the annual report of sampled IBs. After eliminating IBs with insufficient financial and/or Shariah governance information, a sample comprising of 47 individual IBs and 188 firm-year observations for the fiscal years 20062007 (referred as pre-crisis) and 2009-2010 (referred as post-crisis) operating in the Gulf Cooperation Council (GCC) region is obtained.

Consent with the suggestion of Hirschey and Wichern (1984) and, two distinct performance measures: ROA and Tobin's Q are employed to measure the economic performance of IBs. ROA is calculated as the net income available to stockholders divided by total assets. Tobin's Q is computed as the sum of market capitalization and book value of liabilities divided by total assets.

The value added intellectual coefficient (VAIC) devised by Pulic (2000) forms the basis in measuring the efficiency of value added (VA) by a firm's total resources as well as each major resource component (Ho \& Williams, 2003). VAIC ${ }^{1}$ is a composite sum of three indicators termed as: (1) Human Capital Efficiency (HCE), an indicator of the efficiency of VA by human capital resources employed; (2) Structural Capital Efficiency (SCE), an indicator of the efficiency of VA by structural capital; and (3) Capital Employed Efficiency (CEE), which indicates how much value is created for every monetary unit invested in financial or physical capital.

The study also controls for bank-size and leverage as suggested in the previous literature (Beltratti \& Stulz, 2012; Berger \& Bouwman, 2013; Erkens et al., 2012; Majid et al., 2010; Parashar \& Venkatesh, 2010) to account for their potentially confounding effects.

\footnotetext{
${ }^{1}$ Value added of a firm is calculated by subtracting expenses from revenues. HCE is calculated by dividing a company's VA by its expenditures on human capital. SCE is calculated by dividing a company's investment expenses on structural capital by its VA. A firm's CEE is obtained by dividing its VA by the book value of the net assets.
} 


\section{EMPIRICAL RESULTS AND ANALYSIS}

\subsection{Descriptive statistics}

Table 1 reports descriptive statistics for selected firm characteristics, including mean, standard deviation, minimum, maximum, skewness and kurtosis for IBs before (Panel A) and after (Panels B) financial crisis for all variables used in the main analysis.

Table 1: Descriptive Statistics of Performance Measures and Continuous Independent Variables

\begin{tabular}{|c|c|c|c|c|c|c|}
\hline & Mean & Std. Dev. & Min. & Max. & Skew. & Kurt. \\
\hline \multicolumn{7}{|c|}{ Panel A: Before-financial Crisis } \\
\hline$\overline{\mathrm{N}}$ & 94 & 94 & 94 & 94 & 94 & 94 \\
\hline ROA & 2.713 & 1.860 & -3.810 & 3.809 & -2.101 & 6.653 \\
\hline Tobin's Q & 0.760 & 0.273 & 0.245 & 1.126 & -0.793 & 2.398 \\
\hline VAIC & 4.383 & 1.942 & 0.361 & 7.030 & -0.940 & 3.066 \\
\hline $\mathrm{HCE}$ & 3.463 & 1.681 & -0.281 & 5.898 & -0.685 & 2.746 \\
\hline SCE & 0.685 & 0.200 & 0.267 & 1.052 & -1.114 & 3.590 \\
\hline CEE & 0.219 & 0.128 & -0.093 & 0.488 & -0.080 & 3.301 \\
\hline $\operatorname{lnSSB}$ & 4.094 & 1.561 & 2 & 7 & 0.551 & 2.090 \\
\hline lnBSize & 14.239 & 1.419 & 10.787 & 16.836 & -0.763 & 3.144 \\
\hline Lev & 37.649 & 21.897 & 4.369 & 77.986 & 0.530 & 2.215 \\
\hline \multicolumn{7}{|c|}{ Panel B: After-financial Crisis } \\
\hline$\overline{\mathrm{N}}$ & 94 & 94 & 94 & 94 & 94 & 94 \\
\hline ROA & -0.665 & 2.264 & -3.810 & 3.809 & 0.050 & 1.805 \\
\hline Tobin's Q & 0.791 & 0.288 & 0.245 & 1.126 & -0.975 & 2.544 \\
\hline VAIC & 3.467 & 1.982 & 0.361 & 7.030 & 0.045 & 2.302 \\
\hline HCE & 2.399 & 1.889 & -0.281 & 5.898 & 0.051 & 2.187 \\
\hline SCE & 0.722 & 0.235 & 0.267 & 1.052 & -0.222 & 2.450 \\
\hline CEE & 0.155 & 0.164 & -0.094 & 0.488 & 0.239 & 2.349 \\
\hline $\operatorname{lnSSB}$ & 4.078 & 1.372 & 2 & 7 & 0.639 & 2.286 \\
\hline $\operatorname{lnBSize}$ & 14.358 & 1.652 & 10.787 & 16.836 & -0.594 & 2.452 \\
\hline Lev & 44.658 & 20.733 & 4.369 & 77.986 & -0.234 & 2.224 \\
\hline
\end{tabular}

Notes: $\mathrm{ROA}=$ net income available to stockholders/total assets, Tobin's Q = market capitalization + total liabilities / total assets. $\mathrm{VA}=$ total income - total expenses; Human capital $(\mathrm{HC})=$ total personal expenses, $\mathrm{HCE}=\mathrm{VA} / \mathrm{HC}$; Structural capital $(\mathrm{SC})=\mathrm{VA}-\mathrm{HC}, \mathrm{SCE}=\mathrm{SC} / \mathrm{VA}$; Physical capital $(\mathrm{CE})=$ physical and financial capital employed, $\mathrm{CEE}=\mathrm{VA} / \mathrm{CE}$, and VAIC $=\mathrm{HCE}+\mathrm{SCE}+\mathrm{CEE}$. Size of Shariah supervisory board $(\mathrm{SSB})=\log$ of total number of Shariah advisors. Bank-size $($ BSize $)=\log$ of total assets; Level of risk $(\mathrm{Lev})=$ total debt/ total assets.

Overall financial performance of sampled IBs before-crisis is sound as indicated by ROA with a mean of 2.71 , however, it should be noted that the mean of -0.67 for ROA, after- crisis demonstrate the substantial impact of the financial crisis on accounting performance of IBs. As can be noted from Table 1, Tobin's Q increased on average from 0.76 (before-crisis) to 0.79 (after-crisis), suggesting that though IBs are less profitable after the crisis, however, investors' confidence in IBs have increased instead.

As for the continuous independent variables, it can be seen that the average mean of VAIC is 4.38 and 3.47 before- and after-crisis respectively, suggesting that the sampled IBs were generally effective in generating value from their intellectual capital and physical capital base. 
Interestingly, no significant variation in SSB size is observed before- or after-crisis period. However, leverage has increase from 37.65 in pre-crisis to 44.66 in post-crisis period.

\subsection{Correlation analysis}

Table 2 presents correlation results (Panel A for pre-crisis and Panel B for post-crisis) between the dependent variables, ROA and Tobin's Q, and the independent variables. ROA is positively related with VAIC before- and after-crisis, indicating that efficiency in creating corporate value or the extent of corporate intellectual ability enhances firm's financial performance.

Table 2: Correlation Matrix

\begin{tabular}{ccccccccc}
\hline \hline & ROA & Tobin's Q & VAIC & HCE & SCE & CEE & InSSB & InBSize \\
\hline \multicolumn{7}{c}{ Panel A: Before-financial Crisis } \\
\hline Tobin's Q & 0.2179 & & & & & & & \\
VAIC & $\mathbf{0 . 5 0 5 6}$ & $\mathbf{0 . 5 7 8 5}$ & & & & & & \\
HCE & $\mathbf{0 . 6 2 7 9}$ & $\mathbf{0 . 4 9 5 7}$ & $\mathbf{0 . 9 4 1 6}$ & & & & & \\
SCE & 0.2049 & $\mathbf{0 . 4 8 0 5}$ & $\mathbf{0 . 8 3 5 1}$ & $\mathbf{0 . 6 9 4 9}$ & & & & \\
CEE & $\mathbf{0 . 4 5 6 8}$ & $\mathbf{0 . 4 9 5 9}$ & $\mathbf{0 . 4 6 3 1}$ & $\mathbf{0 . 4 5 8 4}$ & 0.298 & & & \\
lnSSB & 0.1362 & -0.041 & 0.0647 & 0.0941 & 0.0497 & 0.0587 & & \\
lnBSize & 0.3713 & $\mathbf{0 . 4 4 3 2}$ & 0.3679 & 0.3718 & 0.2416 & $\mathbf{0 . 5 1 4 5}$ & 0.2928 & \\
Lev & 0.1004 & 0.0131 & 0.0317 & 0.0531 & -0.071 & $\mathbf{0 . 4 4 2 5}$ & 0.1142 & 0.3015 \\
\hline
\end{tabular}

Panel B: After-financial Crisis

\begin{tabular}{cccccccccc}
\hline Tobin's Q & 0.242 & & & & & & & & \\
VAIC & $\mathbf{0 . 5 4 4 7}$ & 0.1503 & & & & & & \\
HCE & $\mathbf{0 . 6 5 6 2}$ & 0.3723 & $\mathbf{0 . 8 5 8 4}$ & & & & & \\
SCE & -0.2846 & -0.1872 & 0.1183 & -0.1472 & & & & \\
CEE & $\mathbf{0 . 6 1 5 2}$ & 0.3769 & $\mathbf{0 . 6 3 6 8}$ & $\mathbf{0 . 7 2 3 5}$ & -0.2966 & & & \\
InSSB & 0.2046 & 0.0304 & 0.121 & 0.1938 & -0.0486 & 0.1431 & & \\
InBSize & 0.3896 & $\mathbf{0 . 4 4 6 1}$ & 0.3515 & $\mathbf{0 . 5 0 4 7}$ & -0.1578 & $\mathbf{0 . 4 6 2 6}$ & 0.3979 & \\
Lev & $\mathbf{0 . 5 7 4 3}$ & -0.0418 & 0.3187 & $\mathbf{0 . 4 1 5 8}$ & -0.3282 & $\mathbf{0 . 6 0 4 1}$ & 0.2241 & $\mathbf{0 . 4 1 7 8}$ \\
\hline \hline
\end{tabular}

Notes: Pearson Correlations significant at the $1 \%$ level are shown in bold.

Similarly, ROA is found to be significantly related with HCE and CEE in a positive direction, while ROA relates positively with SCE before the crisis and negatively after the crisis, however, the relationship is not statistically significant in both the cases. As for the market performance measure; Tobin's Q is significantly and positively associated with VAIC, HCE, SCE, and CEE respectively only before the financial crisis. As for firm-specific variables, firm-size relates positively and significantly with Tobin's Q before- and after-crisis whereas leverage is significantly associated with ROA after crisis.

\subsection{Multivariate analysis}

To examine the effects of IC and Shariah governance (SG) on the economic performance of IBs in pre- and post-financial crisis period, alternative versions of the following panel regression specification are estimated:

$E C O P=\alpha+\beta_{1}$ VAIC $+\beta_{2} S G+\beta_{3}$ Firm $+\varepsilon$ 
Where, ECOP (economic performance) denotes one of the alternative performance measures (ROA or Tobin's Q), SG refers to the Shariah governance proxy of $\operatorname{lnSSB}$ and Firm includes two firm-specific control variables viz. bank-size (BSize) and leverage (Lev).

Note that VAIC is a composite sum of HC, SC, and CE efficiency. To capture the impact of each sub-component of VAIC, four different regression models referred as Model 1, 1a, 1b and 1c for accounting-based performance and Model 2, 2a, 2b and 2c for market-based performance have been run separately, where explanatory variable changes in each equation.

\subsubsection{Accounting performance of IBs before- and after-financial crisis}

Table 3 reports the estimation results of alternative versions of Eq. 1 with ROA as the dependent variable. Models 1, 1a, 1b, and 1c are parsimonious versions of Eq. 1.

Focusing first on the results of Model 1, reported in the second and sixth columns of Table 3, the estimated coefficients for VAIC are positively and statistically significant with ROA at the $1 \%$ level, before-and after-crisis, thereby suggesting that higher VAIC improves IB's profitability. Thus hypothesis $\left(\mathrm{H}_{1.1}\right)$ is supported.

Results from Model 1a, reported in third and seventh columns of Table 3 respectively, indicates significant positive relationship at $1 \%$ level between human capital efficiency and ROA. Likewise, results in Model 1c, reported in the fifth and ninth columns of Table 3 suggest a significant positive relationship at $1 \%$ level between capital employed efficiency and ROA. Therefore, consistent with the hypotheses $\left(\mathrm{H}_{1.1 \mathrm{a}}\right.$ and $\left.\mathrm{H}_{1.1 \mathrm{c}}\right)$ the estimates indicate that strong $\mathrm{HC}$ and $\mathrm{CE}$ efficiency have positive effect on profitability of IBs at all times. Finally, results in Model 1b, reported in the fourth and eighth columns of Table 3 respectively, show no significant relationship between structural capital efficiency and accounting-based performance measure; hence, hypothesis $\left(\mathrm{H}_{1.1 b}\right)$ is rejected.

In contrast, it is interesting to note that the Shariah governance (measured by $\operatorname{lnSSB}$ ) does not relates with the accounting based performance of IBs at all times. Therefore, there is not enough statistically significant evidence to support hypothesis $\left(\mathrm{H}_{2.1}\right)$ for the accounting-based performance measure is rejected. As for firm-related features, leverage relates positively with ROA in the post-crisis period at $10 \%$ level, suggesting that IBs with higher leverage tend to generate higher financial returns.

\subsubsection{Market performance of IBs before- and after-financial crisis}

Table 4 presents the regression results for the effects of IC and Shariah governance on Tobin's Q. Similar to Table 3, alternative versions of Eq. 1 with Tobin's $Q$ as the dependent variable are estimated, where Models 2, 2a, 2b, and 2c are parsimonious versions of Eq. 1.

Consistent with the accounting-based performance of IBs, the estimates indicate that VAIC is positively associated with market valuation of IBs, as the coefficient estimates for VAIC are positive and statistically significant at $1 \%$ and $10 \%$ level respectively before- and after-crisis in both regression specifications, thus, hypothesis $\left(\mathrm{H}_{1.2}\right)$ is supported. Similar results can be observed for the sensitivity analysis, which shows significant positive relationship between Tobin's Q and variables HCE and CEE respectively 


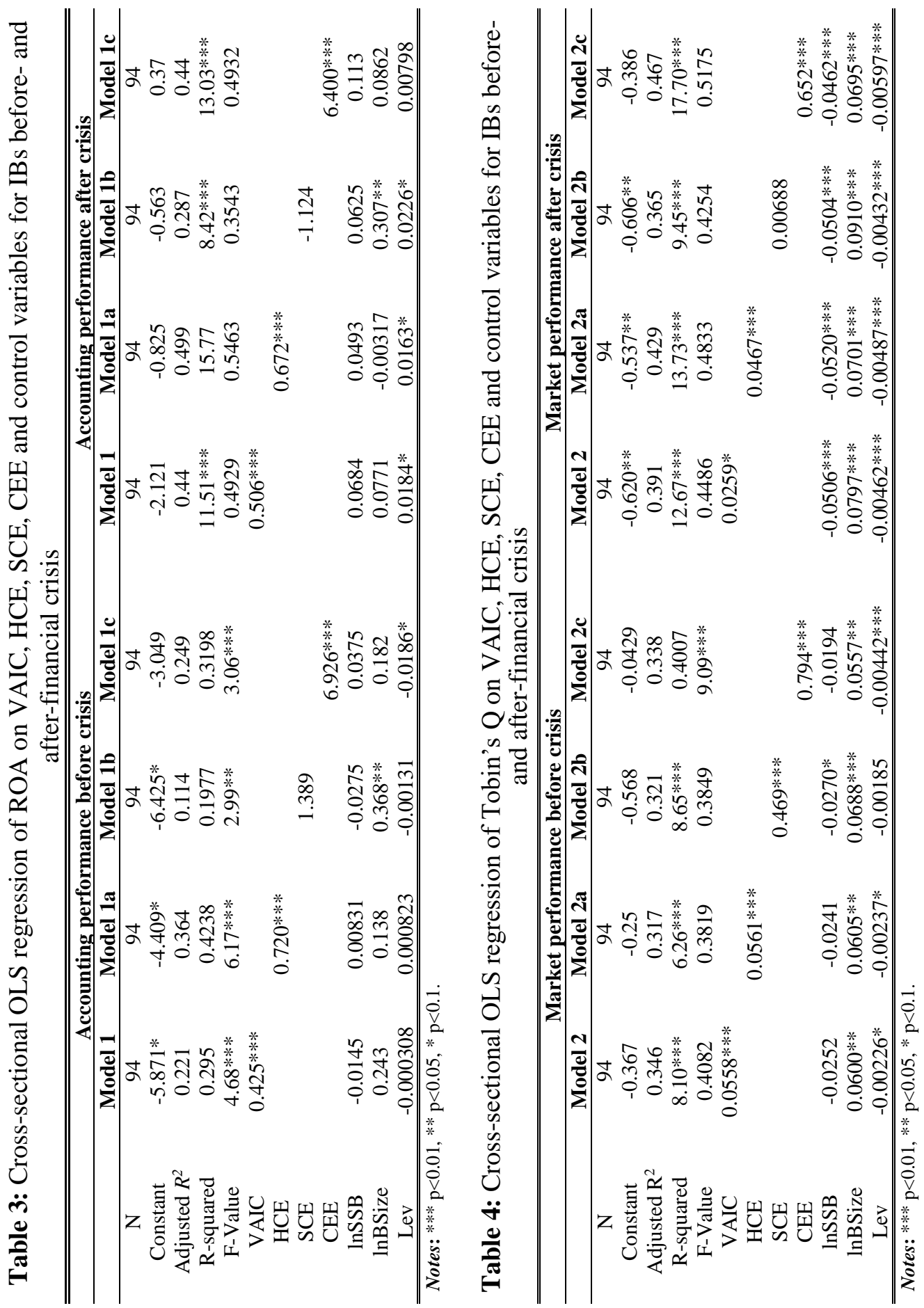


at $1 \%$ level before- and after-crisis, thus, supporting hypotheses $\left(\mathrm{H}_{1.2 \mathrm{a}}\right.$ and $\left.\mathrm{H}_{1.2 \mathrm{c}}\right)$. Inconsistent with the hypothesis $\left(\mathrm{H}_{1.2 \mathrm{~b}}\right)$, the estimates of Model $2 \mathrm{~b}$ indicate that depressed market valuation of IBs in post-crisis period amidst the market meltdown is largely attributable to IBs with weaker SC efficiency.

Interestingly, unlike the account-based performance where no statistical significance was observed, Shariah governance relates negatively with the market-based performance at $1 \%$ level in the post-crisis period. Thus, the results offer strong support for hypothesis $\left(\mathrm{H}_{2.2}\right)$ that there is a significant (negative, in this case) relationship between Shariah governance and market-based performance of IBs. A plausible explanation of this relationship is that the market perceives large SSB as an expense and tends to put negative value to it. The estimated coefficients for firm-specific control variables are highly significant thus, indicating that market valuation increases with firm size and decreases with level of risk.

\section{DISCUSSION OF FINDINGS}

Overall results depict that IC efficiency affects economic performance of sampled IBs at all times. Consistent with the prior literature, these findings indicate that IC generally improves profitability and also has positive effect on market valuation. Thus, consistent with the research hypotheses, the results suggest that the financial crisis may have spurred the impact of IC on the growth and profitability of IBs and their potential market share even further.

However, it should be noted that this finding is broadly consistent with do Rosário Cabrita and Vaz (2005) and Yalama and Coskun (2007) in pre-crisis period and with Ting and Lean (2009) and Muhammad and Ismail (2009) in post-crisis period, who document that IC attributes are positively associated with financial performance of conventional banks. Equally, sustained market-based performance of IBs before- and after-crisis, endorses the findings of Youndt et al. (2004) and Adams and Santos (2006), before-financial distress whereas the results observed aftermath of the market meltdown agree with Maditinos, Chatzoudes, Tsairidis, and Theriou (2011) and Sumedrea (2013), who posit that IC has a strong impact on the competitive advantage and market capitalization. The sensitivity analysis suggest that strong CE efficiency and HC efficiency play a pivotal role in determining the financial- and market-based performance of IBs, before- and after-crisis. Financial and physical capital is important at all times for IBs, because they have no access to the financial market in the event of unanticipated needs as this would have involved interest transactions.

On the other hand, the mixed evidence for the Shariah governance (SG) hypotheses suggests that $\mathrm{SG}$ alone is not enough to explain the value creation and stability of Islamic banking sector. Despite the observed results in this study, the significance of SG in Islamic way of banking shall not be undermined. Islamic banking industry is comparatively way smaller than their conventional rivals so as the IBs. IBs mainly engage in relationship lending, and long-term bank borrower relationships are crucial in Ongena and Smith (2001) for relationship banking to create value. This means that relationship borrowers gravitate toward high-capital banks (Berger \& Bouwman, 2013), because higher capital 
leads to a higher profitability and higher probability of survival at all times. Likewise, HC efficiency played a crucial role in determining the financial health and market-valuation of sampled IBs at all times. The results corroborate human IC is the precursor for the intellectual wealth of an IB (see also Colombo \& Grilli, 2005). Since newly developed services must not violate divine guidelines, therefore, consistent with Dotzel et al. (2013), it is argued that service innovativeness in Islamic finance is enabled primarily by human IC, which effects positively on economic performance of IBs. Hence, with the development of human IC, IB's ability to merchandise its IC improves resulting in higher profitability and market valuation. This interface finds support in the earlier studies (i.e., Chen et al., 2014; Holland, 2010; Mention \& Bontis, 2013), who reported that human IC contributes both directly and indirectly to business performance in the banking sector.

On the other hand, consistent with earlier research (e.g., Aebi, Sabato, \& Schmid, 2012; Beltratti \& Stulz, 2012; Fahlenbrach \& Stulz, 2011), the study finds either no significant or even a negative relation between corporate governance variable $(\operatorname{lnSSB}$, for Shariah governance) and economic performance of IBs in all times i.e. pre- and post-financial crisis period. Hence, the results suggest that since SSB has no executive function or strategic role; these are the responsibilities of the Islamic banks' boards of directors (see Ahmed et al., 2014) therefore, Shariah governance may fall short in explaining the economic performance of IBs.

\section{CONCLUSION}

Islamic finance is still a rapidly evolving area and new research is clearly needed to understand the key dynamics of such way of banking in the networked economy. Given the divergent nature of the present study, which provides evidence from a hitherto underresearched topic i.e. Islamic banking and finance, the observed findings have sensible economic interpretations. First, higher efficiency of knowledge-resources i.e. IC helps IBs to improve their odds of survival at all times i.e. before- and after-crisis. Second, higher IC efficiency helps IBs to maintain their profitability i.e. ROA and market valuation at all times. Arguably, knowledge-resources i.e. intellectual capital is the main line of defence for IBs against negative shocks.

\section{REFERENCES}

Abdelsalam, O., Fethi, M. D., Matallín, J. C., \& Tortosa-Ausina, E. (2014). On the comparative performance of socially responsible and Islamic mutual funds. Journal of Economic Behavior \& Organization, 103, S108-S128.

Abedifar, P., Molyneux, P., \& Tarazi, A. (2013). Risk in Islamic banking. Review of Finance, 17(6), 2035-2096.

Adams, R. B., \& Santos, J. A. (2006). Identifying the effect of managerial control on firm performance. Journal of Accounting and Economics, 41(1), 55-85.

Aebi, V., Sabato, G., \& Schmid, M. (2012). Risk management, corporate governance, and bank performance in the financial crisis. Journal of Banking \& Finance, 36(12), 3213-3226.

Ahmed, H. (2011). Maqasid al-Shari'ah and Islamic financial products: a framework for assessment. ISRA International journal of Islamic finance, 3(1), 149-160. 
Ahmed, H., Mehmet, A., \& Rodney, W. (2014). Reflecting on islamic banking and financial crisis reputation stability and risks. In A. Habib, M. Asutay \& R. Wilson (Eds.), Islamic banking and finance crisis: reputation stability and risks (pp. 1-20). Edinburgh: Edinburgh University Press Ltd.

Athanasoglou, P. P., Brissimis, S. N., \& Delis, M. D. (2008). Bank-specific, industryspecific and macroeconomic determinants of bank profitability. Journal of International Financial Markets, Institutions and Money, 18(2), 121-136.

Baele, L., Farooq, M., \& Ongena, S. (2014). Of religion and redemption: Evidence from default on Islamic loans. Journal of Banking \& Finance, 44, 141-159.

Bebchuk, L. A., \& Spamann, H. (2009). Regulating bankers' pay. Georgetown Law Journal, 98(2), 247-287.

Beck, T., Demirgüç-Kunt, A., \& Merrouche, O. (2013). Islamic vs. conventional banking: Business model, efficiency and stability. Journal of Banking \& Finance, 37(2), 433-447.

Beltratti, A., \& Stulz, R. M. (2012). The credit crisis around the globe: Why did some banks perform better? Journal of Financial Economics, 105(1), 1-17.

Berger, A. N., \& Bouwman, C. H. (2013). How does capital affect bank performance during financial crises? Journal of Financial Economics, 109(1), 146-176.

Bharadwaj, A. S. (2000). A resource-based perspective on information technology capability and firm performance: an empirical investigation. MIS quarterly, 24(1), 169-196.

Bourkhis, K., \& Nabi, M. S. (2013). Islamic and conventional banks' soundness during the 2007-2008 financial crisis. Review of Financial Economics, 22(2), 68-77.

Chen, L., Danbolt, J., \& Holland, J. (2014). Rethinking bank business models: the role of intangibles. Accounting, Auditing \& Accountability Journal, 27(3), 563-589.

Čihák, M., \& Hesse, H. (2010). Islamic banks and financial stability: an empirical analysis. Journal of Financial Services Research, 38(2-3), 95-113.

Colombo, M. G., \& Grilli, L. (2005). Founders' human capital and the growth of new technology-based firms: A competence-based view. Research policy, 34(6), 795-816.

De Brentani, U., \& Kleinschmidt, E. J. (2004). Corporate culture and commitment: impact on performance of international new product development programs. Journal of product innovation management, 21(5), 309-333.

de Castro, G. M., \& Sáez, P. L. (2008). Intellectual capital in high-tech firms: The case of Spain. Journal of Intellectual Capital, 9(1), 25-36.

Diamond, D. W., \& Rajan, R. (2009). The credit crisis: Conjectures about causes and remedies. NBER Working Paper No. 14739.

Dietrich, A., \& Wanzenried, G. (2011). Determinants of bank profitability before and during the crisis: Evidence from Switzerland. Journal of International Financial Markets, Institutions and Money, 21(3), 307-327.

do Rosário Cabrita, M., \& Vaz, J. L. (2005). Intellectual Capital and Value Creation: Evidence from the Por-tuguese Banking Industry. Electronic Journal of Knowledge Management, 4(1), 11-20.

Dotzel, T., Shankar, V., \& Berry, L. L. (2013). Service innovativeness and firm value. Journal of Marketing Research, 50(2), 259-276.

Ebrahim, M. S. (2009). Can an Islamic model of housing finance cooperative elevate the economic status of the underprivileged? Journal of Economic Behavior \& Organization, 72(3), 864-883.

Edvinsson, L., \& Malone, M. S. (1997). Intellectual Capital: Realizing Your Company's True Value by Finding Its Hidden Roots. New York: HarperCollins Publishers, Inc. 
Elnahass, M., Izzeldin, M., \& Abdelsalam, O. (2014). Loan loss provisions, bank valuations and discretion: A comparative study between conventional and Islamic banks. Journal of Economic Behavior \& Organization, 103(Supplement), S160-S173 .

Erkens, D. H., Hung, M., \& Matos, P. (2012). Corporate governance in the 2007-2008 financial crisis: Evidence from financial institutions worldwide. Journal of Corporate Finance, 18(2), 389-411.

Fahlenbrach, R., \& Stulz, R. M. (2011). Bank CEO incentives and the credit crisis. Journal of financial economics, 99(1), 11-26.

Florin, J., Lubatkin, M., \& Schulze, W. (2003). A social capital model of high-growth ventures. Academy of Management Journal, 46(3), 374-384.

Garcia-Appendini, E., \& Montoriol-Garriga, J. (2013). Firms as liquidity providers: Evidence from the 2007-2008 financial crisis. Journal of financial economics, 109(1), 272-291.

Haneef, R., \& Smolo, E. (2014). Reshaping the Islamic finance industry: Applying the lessons learned from the global financail crisis. In H. Ahmed, A. Mehmet \& R. Wilson (Eds.), Islamic Banking and Financial Crisis Reputation Stability and Risks (pp. 21-39). Edinburgh: Edinburgh University Press Ltd.

Haniffa, R., \& Hudaib, M. (2002). A Theoretical Framework for the Development of the Islamic Perspective of Accounting. Accounting, Commerce and Finance: The Islamic Perspective Journal, 6(1\&2), 1-71.

Hasan, M., \& Dridi, J. (2010). The effects of the global crisis on Islamic and conventional banks: A comparative study. IMF Working Paper No. WP/10/201.

Hirschey, M., \& Wichern, D. W. (1984). Accounting and market-value measures of profitability: Consistency, determinants, and uses. Journal of Business \& Economic Statistics, 2(4), 375-383.

Ho, C.-A., \& Williams, S. M. (2003). International comparative analysis of the association between board structure and the efficiency of value added by a firm from its physical capital and intellectual capital resources. The International Journal of Accounting, 38(4), 465-491.

Holland, J. (2010). Banks, knowledge and crisis: a case of knowledge and learning failure. Journal of Financial Regulation and Compliance, 18(2), 87-105.

Hsu, L. C., \& Wang, C. H. (2012). Clarifying the effect of intellectual capital on performance: the mediating role of dynamic capability. British Journal of Management, 23(2), 179-205.

Johnes, J., Izzeldin, M., \& Pappas, V. (2014). A comparison of performance of Islamic and conventional banks 2004-2009. Journal of Economic Behavior \& Organization, 103, S93-S107.

Kashyap, A., Rajan, R., \& Stein, J. (2008). Rethinking capital regulation. Economic Policy Symposium, 431-471.

Khan, A. K. (2010). God, government and outsiders: The influence of religious beliefs on depositor behavior in an emerging market. Harvard, Cambridge MA.

Maditinos, D., Chatzoudes, D., Tsairidis, C., \& Theriou, G. (2011). The impact of intellectual capital on firms' market value and financial performance. Journal of Intellectual Capital, 12(1), 132-151.

Majid, A. M., Saal, D. S., \& Battisti, G. (2010). Efficiency in Islamic and conventional banking: an international comparison. Journal of Productivity Analysis, 34(1), 25-43. 
Mallin, C., Farag, H., \& Ow-Yong, K. (2014). Corporate social responsibility and financial performance in Islamic banks. Journal of Economic Behavior \& Organization, 103, S21-S38.

Mention, A.-L., \& Bontis, N. (2013). Intellectual capital and performance within the banking sector of Luxembourg and Belgium. Journal of Intellectual Capital, 14(2), 286-309.

Muhammad, N. M. N., \& Ismail, M. K. A. (2009). Intellectual capital efficiency and firm's performance: Study on Malaysian Financial Sectors. International Journal of Economics and Finance, 1(2), 206-212.

Murthy, V., \& Mouritsen, J. (2011). The performance of intellectual capital: mobilising relationships between intellectual and financial capital in a bank. Accounting, Auditing \& Accountability Journal, 24(5), 622-646.

Nawaz, T. (2013). How serious is the Erudite Shariah-compliant Business in Europe? Evolution, Pivotal Challenges and the way forward. European Journal of Management and Management, 4(6), 226-235.

Nawaz, T. (2015). Ethical Banking in the Land of Redistributive Policies. Saarbruchen, Germany: Scholars Press.

Nawaz, T. (2016). Talent Management and Corporate Governance: The Case of Islamic Finance. International Journal of Management and Applied Science, 2(7), 58-61.

Nawaz, T. (2017). Momentum Investment Strategies, Corporate Governance, and Firm Performance: An Analysis of Islamic Banks. Corporate Governance: The International Journal of Business in Society, 17(2), in press.

Nazim, A., \& Bennie, G. (2012). World Islamic Banking Competitiveness Report 2012 2013. Ernst \& Young.

Ongena, S., \& Şendeniz-Yüncü, İ. (2011). Which firms engage small, foreign, or state banks? And who goes Islamic? Evidence from Turkey. Journal of Banking \& Finance, 35(12), 3213-3224.

Ongena, S., \& Smith, D. C. (2001). The duration of bank relationships. Journal of financial economics, 61(3), 449-475.

Parashar, S. P., \& Venkatesh, J. (2010). How did Islamic banks do during global financial crisis. Banks and Bank systems, 5(4), 54-62.

Pulic, A. (2000). VAIC ${ }^{\text {TM}}$-an accounting tool for IC management. International journal of technology management, 20(5-8), 702-714.

Stewart, T., \& Ruckdeschel, C. (1998). Intellectual capital: The new wealth of organizations. Performance Improvement, 37(7), 56-59.

Sullivan, P. H. (2000). Value driven intellectual capital: how to convert intangible corporate assets into market value. New York: John Wiley \& Sons, Inc.

Sumedrea, S. (2013). Intellectual Capital and Firm Performance: A Dynamic Relationship in Crisis Time. Procedia Economics and Finance, 6, 137-144.

Sveiby, K. E. (1997). The new organizational wealth: Managing \& measuring knowledgebased assets. San Francisco: Berrett-Koehler Publishers.

Taylor, J. B. (2009). The financial crisis and the policy responses: An empirical analysis of what went wrong. NBER Working Paper No. 14631.

Ting, I. W. K., \& Lean, H. H. (2009). Intellectual capital performance of financial institutions in Malaysia. Journal of Intellectual Capital, 10(4), 588-599.

Yalama, A., \& Coskun, M. (2007). Intellectual capital performance of quoted banks on the Istanbul stock exchange market. Journal of Intellectual Capital, 8(2), 256-271.

Youndt, M. A., Subramaniam, M., \& Snell, S. A. (2004). Intellectual Capital Profiles: An Examination of Investments and Returns. Journal of Management Studies, 41(2), 335-361. 